\title{
Fabrication, Characterization and Machining of Al6061 Reinforced with Red Mud Composite
}

\author{
Poorna Chandra1 $^{1}$, V. Ravi Kumar¹, R. Kiran¹, D. V. Ravi Kumar1, C. R. Prakash Rao', R. Suresh ${ }^{2}$ \\ ${ }^{1}$ Department of Mechanical Engineering, Global Academy of Technology, Bengaluru, India \\ ${ }^{2}$ Department of Industrial \& Automation Engineering, VTU PG Centre, Mysuru, India \\ Email: * poornachandra.lec@gmail.com
}

How to cite this paper: Chandra, P., Kumar, V.R., Kiran, R., Ravi Kumar, D.V., Rao, C.R.P. and Suresh, R. (2022) Fabrication, Characterization and Machining of Al6061 Reinforced with Red Mud Composite. Journal of Minerals and Materials Characterization and Engineering, 10, 28-42. https://doi.org/10.4236/jmmce.2022.101003

Received: November 27, 2021

Accepted: January 21, 2022

Published: January 24, 2022

Copyright $\odot 2022$ by author(s) and Scientific Research Publishing Inc. This work is licensed under the Creative Commons Attribution International License (CC BY 4.0).

http://creativecommons.org/licenses/by/4.0/

\begin{abstract}
The Metal Matrix Composites application has increased in many areas of science and technology, because of its additional physical, wear and mechanical properties. In comparison with all MMC's, aluminum-based MMC's are finding wide applications due to their better strength to weight ratio, better stiffness, and high thermal conductivity as well as very good wear and corrosion properties. The properties of a composite mainly depend on better distribution of reinforcement in the matrix, which is very difficult to achieve. Basically Redmud is a byproduct of alumina, and it is waste product obtained during Bayer's process. This waste product must be recycled else it may be dangerous to the environment. Redmud can be used as reinforcement for aluminium composites in order to achieve better properties. The proposed research work includes preparation of Aluminum 6061-Red mud metal matrix composites using liquid metallurgy route following stir casting technique. An alloy Al6061 containing 0.60 percent silicon and Magnesium of 0.82 percent was used as the matrix material. Two different compositions of the Aluminum 6061-Red mud composites are prepared in addition to the base matrix and evaluated for mechanical properties also the force acting on the cutting tool at different spindle speeds during machining of the composite materials were analyzed.
\end{abstract}

\section{Keywords}

Al6061, Redmud, Machining, MMC's, Cutting Force Measurement

\section{Introduction}

Composite materials are majorly preferred in current technology, because of their wide advantages which makes it more suitable in many sectors namely, automotive, aircraft, marine etc. The main reason behind this is the strength to 
weight ratio, this makes it more suitable for many industrial applications.

In order to achieve better properties a new composite material with improved physical and mechanical properties need to be developed. Excessive research has been carried out to understand the structure, property and nature of materials. From survey, it was found that Stir casting technique can be performed to develop a composite material with different reinforcements [1] and with proper stirring method. The aluminum matrix reinforced with different weight fractions of silicon carbide using molten metal method showed increase in hardness, impact strength of the composite. The homogeneous dispersion of silicon carbide particles in metal matrix was achieved with manual two-step stir casting method [2]. During casting of $\mathrm{SiC}$ reinforced with $\mathrm{Al}-10 \%$, it was found that the Sic particles were distributed uniformly in the matrix and the processing temperature was $700^{\circ} \mathrm{C}$ to $800^{\circ} \mathrm{C}$ at $10 \mathrm{~min}$ holding time [3], there was gradual increase in ultimate strength and hardness. In melting process carried out using muffle furnace and graphite crucible with $\mathrm{Al}-\mathrm{Cu}-\mathrm{Mg}$ alloy reinforced with preheated Sic- $\mathrm{Al}_{2} \mathrm{O}_{3}$ particles at $700^{\circ} \mathrm{C}$, found increase in hardness, ultimate tensile strength, elastic modulus [4].

The effect of density, hardness, porosity investigated during fabrication of AA6061 alloy reinforced with $\mathrm{Al}_{2} \mathrm{O}_{3}$ and red mud particles at varying percentages, the results showed improvement in hardness and tensile strength with increase in reinforcement [5]. During dry machining of aluminium and fly ash composite it was observed that the cutting tool fails due formation of built-up edge. But at higher speed and feed due to higher chip velocity breakdown of built up edge takes place, in turn the tool life increases [6] [7] [8]. In machining of hybrid MMC's it was inferred that as the cutting speed, feed increases the contact time of the insert decreases. Also it was found that due to reduced contact time of inserts the wear resistance of HMMC's was higher [9] [10] [11] [12]. As the weight percentage of Silicon Carbide particles increases in cast MMC's, the hardness of the composite is found higher with reduction in forgeability. At different cutting speed and constant feed rate the cutting forces increases with increase in depth of cut mean while the power consumption also increases [13] [14] [15].

During machining of cast $\mathrm{Al}-\mathrm{TiC}$ composite it was observed that cutting force increases with increase in feed rate and constant speed for all weight fractions mean while cutting force decreases with increase in cutting speed this may be due to reduced friction rate at higher speeds [16]. Higher the value of cutting force was found while machining under dry condition with higher feed rate and depth of cut. The BUE formation rate was prominent at lower speed [17]. The decrease in the surface roughness values can be explained that the possibility of BUE formation reduces with the increased cutting speed. The surface finish and cutting forces remained unaffected when new cutting tool was used for machining of the mmc's, however, the BUE was found lower when new PCD insert were used for machining [18] [19]. The interaction between cutting speed and depth of cut was found more significant, the authors considered the failure of the cutting tool in term of flank wear and crater wear [20]. Addition of reinforcement 
$\mathrm{SiC}$ to the composite material reduces elongation of the composite and increases the hardness of the composite material. The authors observed that machining variable rate of feed is the most influencing factor for cutting temperature. The cutting force found higher at higher rate of feed and higher depth of cut. This is due to the fact that the rate of material removal is higher and hence significant power is required for removing the chip from the work material [21].

In the present research work Aluminium-Redmud composite was prepared using stir casting method, varied percent redmud was used to fabricate the composite material. The newly developed composite material was subjected to hardness, density and SEM analysis. Machining tests were carried out to find the cutting forces using varied machining parameters.

\section{Experimental Data}

\subsection{Matrix \& Reinforcement}

In the current study, Al6061 is selected as matrix material due to its wide advantages namely good corrosion resistance, high damping capability, good thermal \& electrical conductivity which majorly consist of Fe- $0.25 \%$, Si- $0.6 \% \mathrm{Mg}-0.82 \%$ weight ratio. Figure 1 shows Al6061 matrix material.

Redmud basically an industrial waste which is a byproduct obtained during extraction of alumina by Bayer's process, it majorly consists of 30 to 60 percent of ferrous oxide, 10 to 20 percent of aluminium oxide, 350 percent silicon carbide and 2 to 10 percent sodium oxide and 24 percent titanium oxide. Also Redmud is abundantly available and low cost material, hence currently Redmud is selected as reinforcement material as shown in Figure 2. Chemical composition of Aluminum alloy and Redmud particles are as shown in Table $1 \&$ Table 2 respectively.

\subsection{Preparation of Mould}

The sand mixture is prepared by adding binder i.e. bentonite, coal dust as additive and water. The sand is prepared by hand mixing. After preparation of moulding sand, the mould is prepared by ramming the sand in the mould box. A pattern of size $300 \mathrm{~mm}$ length $\times 100 \mathrm{~mm}$ diameter is selected for preparation of mould cavity. Later vent holes are created in the mould in order to remove the hot gases generated during pouring of molten metal in casting process and mould is preheated. Figure 3 and Figure 4 show preheating of mould and the mould box ready for casting respectively.

\subsection{Fabrication of Composite Material}

Fabrication of composite is carried out using Stir casting process. In this method proper weight fraction of Aluminium-Al 60601 is placed in graphite crucible and heated up to molten state in electric induction furnace.

Figure 5 shows Stirring process used to fabricate the aluminum with Redmud particles. Degassing is carried out using hexacholoro ethane tablets. Figure 6 
shows the molten composite pouring into a preheated sand mould box of 300 $\mathrm{mm}$ length and $100 \mathrm{~mm}$ diameter. Figure 7 shows casted Aluminum metal matrix composite, Figure 8 shows preturned Aluminum metal matrix composite specimen of size $300 \mathrm{~mm}$ length and $100 \mathrm{~mm}$ diameter ready for conducting the experiment.

Table 1. Chemical composition of Aluminum alloy.

\begin{tabular}{ccccc}
\hline Material & Fe Si Mn & $\mathrm{Zn} \mathrm{Cu} \mathrm{Ti}$ & $\mathrm{Cr}$ & $\mathrm{Mg} \mathrm{Al}$ \\
\hline Weight\% & 0.250 .600 .03 & 0.10 .220 .1 & 0.24 & 0.82 Remaining \\
\hline
\end{tabular}

Table 2. Chemical composition of Redmud.

\begin{tabular}{cccccccc}
\hline Material & $\mathrm{Al}_{2} \mathrm{O}_{3}$ & $\mathrm{Fe}_{2} \mathrm{O}_{3}$ & $\mathrm{SiO}_{2}$ & $\mathrm{TiO}_{2}$ & $\mathrm{Na}_{2} \mathrm{O}$ & $\mathrm{CaO}$ & LOI \\
\hline Weight\% & $17-20$ & $44-47$ & $7-9$ & $8-11$ & $17-20$ & $44-47$ & $7-9$ \\
\hline
\end{tabular}

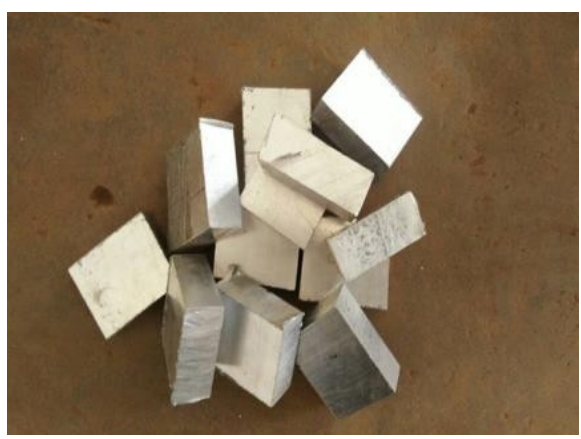

Figure 1. Al6061 Alloy.

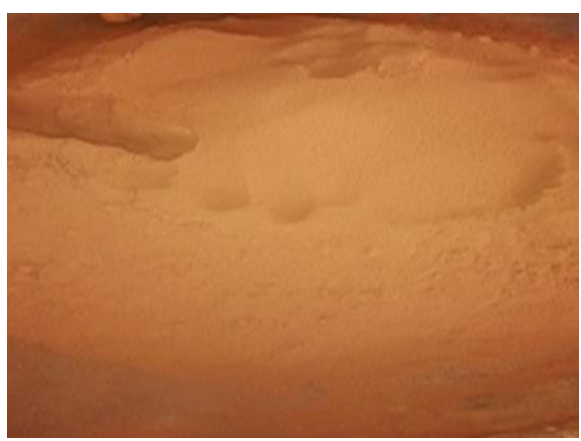

Figure 2. Redmud material.

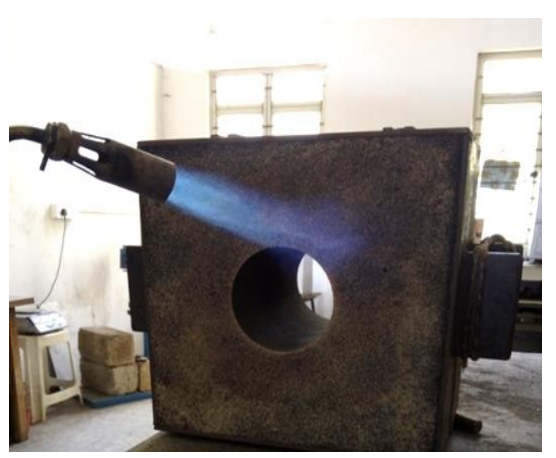

Figure 3. Preheating of mould. 


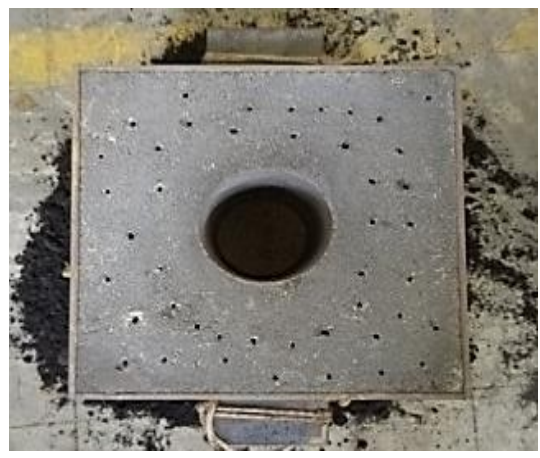

Figure 4. Mould ready for casting.

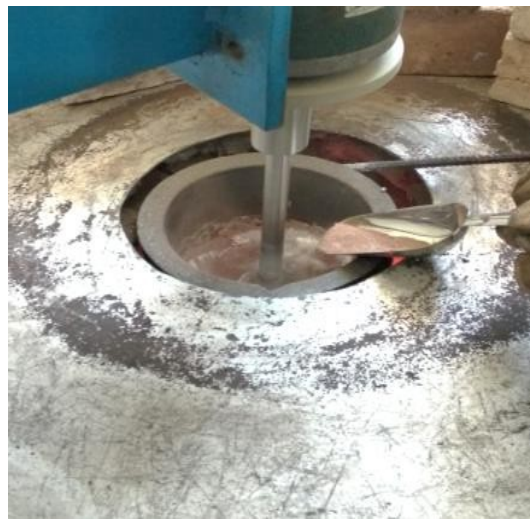

Figure 5. Preparation of Aluminum metal matrix composite.

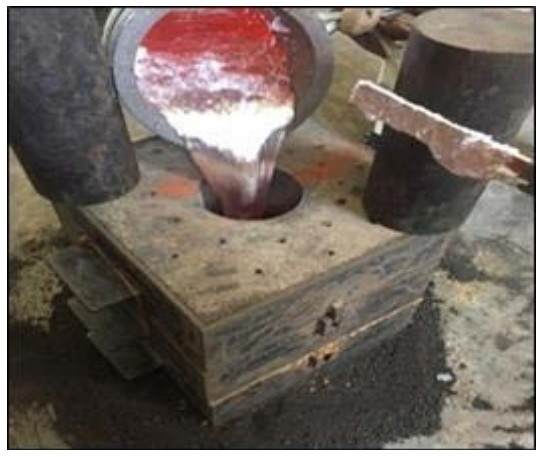

Figure 6. Pouring molten Aluminum metal matrix composite into cavity.

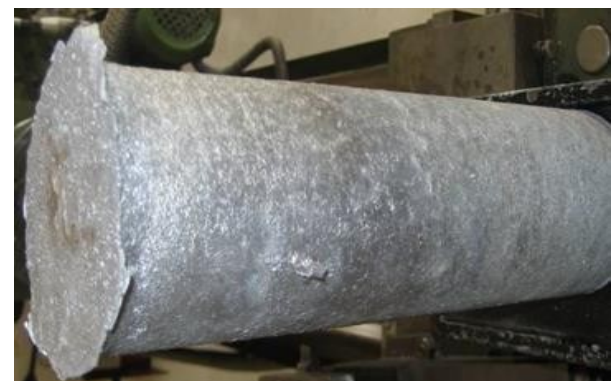

Figure 7. Casted Aluminum metal matrix composite. 


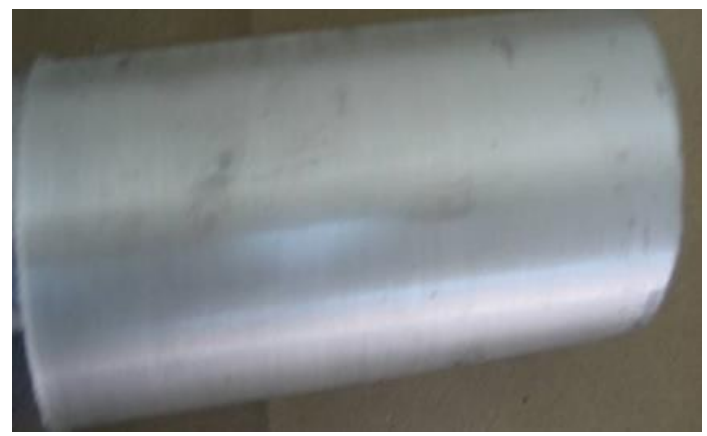

Figure 8. Aluminum metal matrix composite specimen ready for experiment.

\section{Machining of Composite Material}

Machining of composite material is performed on JOBBER XL CNC Lathe. The casted composite material is machined to inspect different mechanical properties and the cutting force acting on the tool at varied cutting speed.

\subsection{Cutting Tool}

The cutting tools used for the experiments are throw away type tungsten carbide inserts. Positive rake tool holder of $25 \mathrm{~mm}$ shank size is used for the machining application. Figure 9 shows the tool holder and the tungsten carbide inserts used for conducting the experiment.

\subsection{Machine Tool}

Machining of composite material is performed on JOBBER XL CNC Lathe is shown in Figure 10. The machined composites with $0 \%, 3 \%$ \& $6 \%$ Redmud are used to conduct the experiment. The specification Jobber XL CNC Lathe and machined samples are shown in Table 3 \& Figures 11-13 respectively.

\section{Experimental Results \& Discussion}

\subsection{Hardness Measurement}

The Brinell hardness tests were conducted in accordance using ASTM standards on KB3000H model Krystal Elmec make Brinell Hardness Tester as shown in Figure 14.

Table 3. Specification of Jobber XL CNC Lathe.

\begin{tabular}{cc}
\hline & Machine Tool Specification \\
\hline Maximum diameter which can be machined & $270 \mathrm{~mm}$ \\
Maximum length which can be machined & $400 \mathrm{~mm}$ \\
Spindle speed range & $50-400 \mathrm{RPM}$ \\
Job clamping system & Hydraulic \\
Dimension of CNC lathe & $2200 \times 1750 \times 1750$ in $\mathrm{mm}$ \\
\hline
\end{tabular}




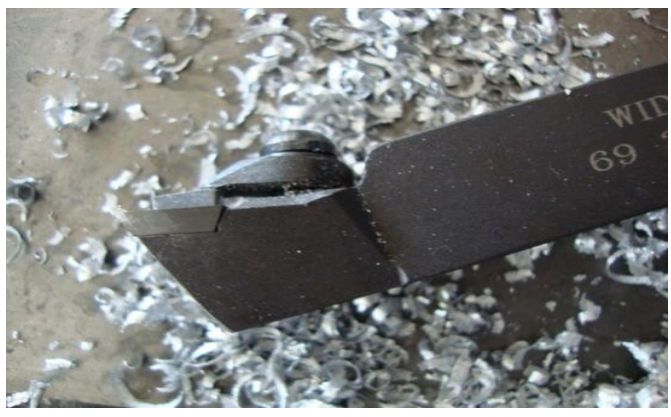

Figure 9. Cutting tool used for the experiment.

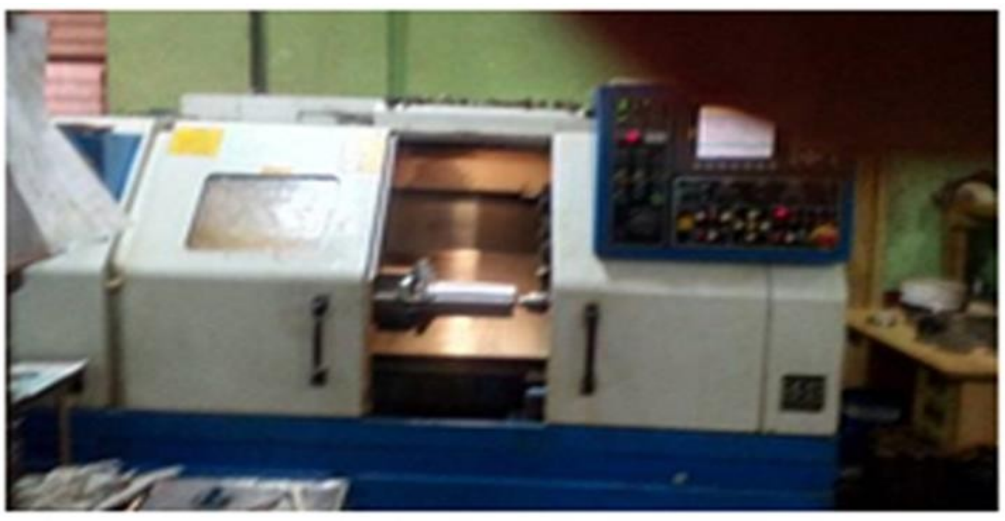

Figure 10. JOBBER XL CNC Lathe used for the experiment.

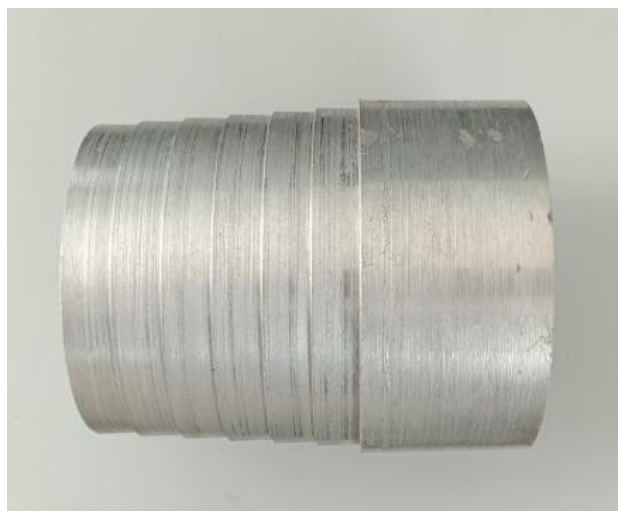

Figure 11. Machined Al6061 with 0\% RM.

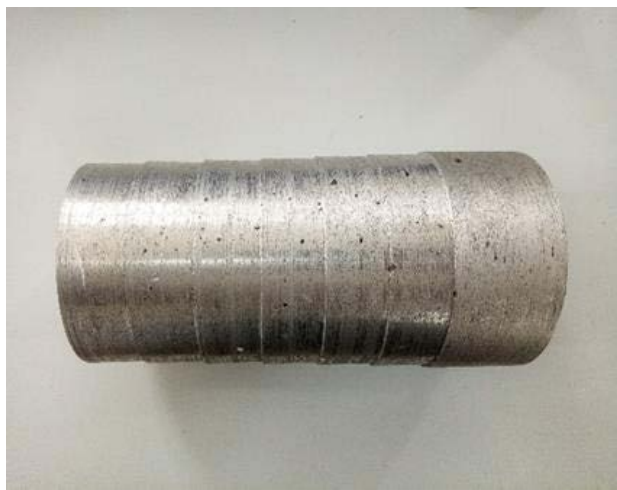

Figure 12. Machined Al with 3\% RM. 


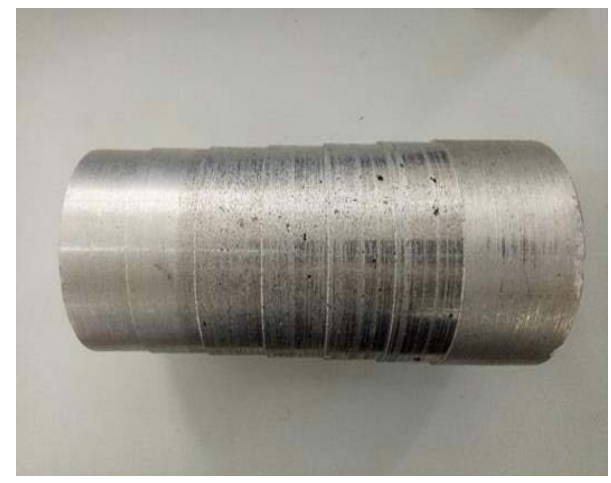

Figure 13. Machined Al with 6\% RM.

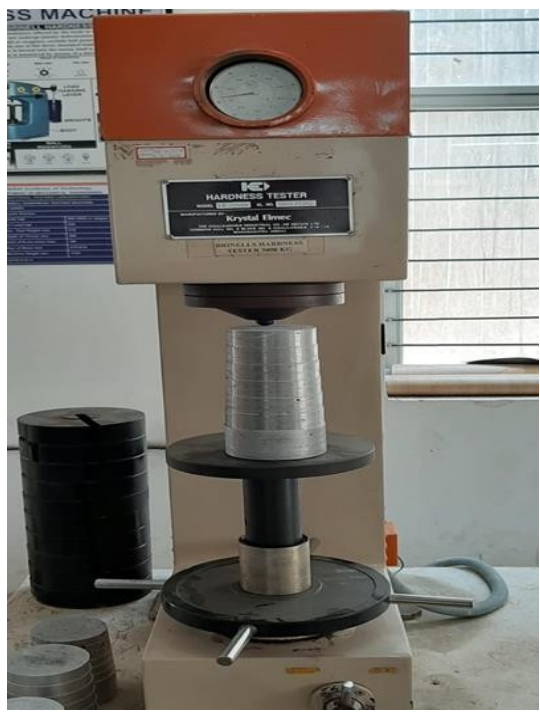

Figure 14. Krystal elmec brinell hardness tester.

The hardness of the material is as shown in Table 4. It was found that Al6061 aluminium alloy without any reinforcement the hardness obtained was $38 \mathrm{BHN}$, with addition of $3 \%$ Redmud reinforcement the hardness was found to be 47 BHN and with addition of $6 \%$ reinforcement the hardness increased to $56 \mathrm{BHN}$. Figure 15 shows the influence of Redmud reinforcement on hardness of the material. It is also observed that hardness of the composite material found higher than matrix material. Hardness of the composite material containing $6 \%$ redmud found higher than other two specimens.

\subsection{Density Measurement}

Density measurements were carried out on the base alloy and reinforced samples using Archimedes' principle. The density of metal matrix aluminium Al6061 without any reinforcement was found to be $2.70 \mathrm{gm} / \mathrm{cc}$. With the addition of $3 \%$ and $6 \%$ Redmud reinforcement the density values were $2.63 \& 2.58$ respectively. It can be observed that as the percent reinforcement increases the density of the composite material decreases as shown in Table 5. Figure 16 shows the Influence of Redmud reinforcement on density of the material. 


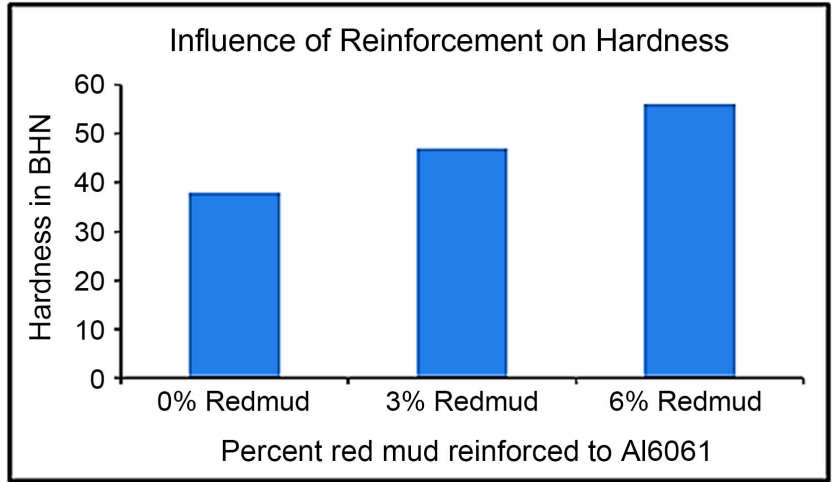

Figure 15. Influence of Redmud reinforcement on hardness of the material.

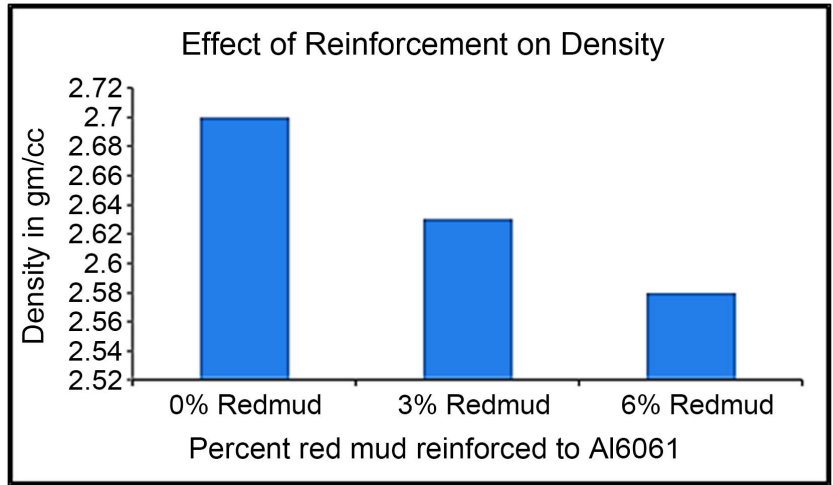

Figure 16. Influence of Redmud reinforcement on density of the material.

Table 4. Hardness of composite material.

\begin{tabular}{cc}
\hline Material & Brinell Hardness Number \\
\hline AL6061+ 0\% Redmud & 38 \\
AL6061+3\% Redmud & 47 \\
AL6061+6\% Redmud & 56 \\
\hline
\end{tabular}

Table 5. Density of composite material.

\begin{tabular}{cc}
\hline Material & Density $(\mathrm{gm} / \mathrm{cc})$ \\
\hline AL6061+ 0\% Redmud & 2.70 \\
AL6061+3\% Redmud & 2.63 \\
AL6061+6\% Redmud & 2.58 \\
\hline
\end{tabular}

\subsection{Analysis of Micro Structure}

Figure 17 shows the scanning electron microscope used to conduct the microstructural examinations. Figure 18(a) shows the SEM Microphotographs of the Al6061 grade aluminum alloy used for the experiments. Figure 18(b) shows the SEM Microphotographs of the Al6061 grade aluminum alloy reinforced with 3\% redmud and Figure 18(c) shows the SEM Microphotographs of the Al6061 grade aluminum alloy reinforced with $6 \%$ redmud. From, Figure 18(b) and Figure 18 (c), it is clear that the distribution of the red mud particles in the matrix is 
uniform and hence the method selected to prepare the composite material is proved.

\subsection{Cutting Force Measurement and Analysis}

The cutting force acting on the cutting tool at varied speed and feed per revolution at constant depth of cut is analyzed for both matrix material and the composite containing varied percentage of redmud. Figures 19-24 show the analysis of the cutting force acting on different composite material. It is observed that as the cutting speed increases the cutting force acting on tool decreases and increase of feed per revolution leads to increase of cutting force.

Figure 25 shows the built up edge problem observed while machining aluminum-redmud composite material.

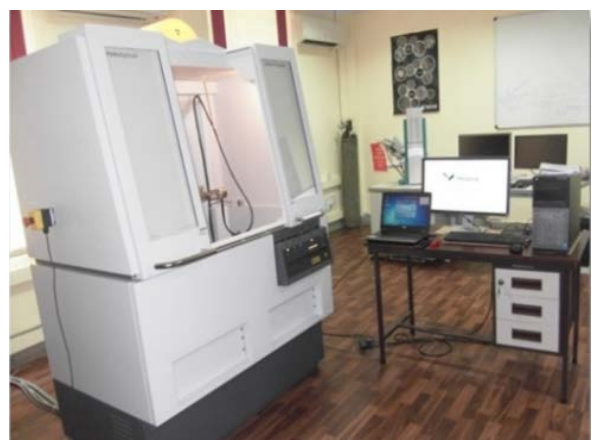

Figure 17. SEM used for the experiments.

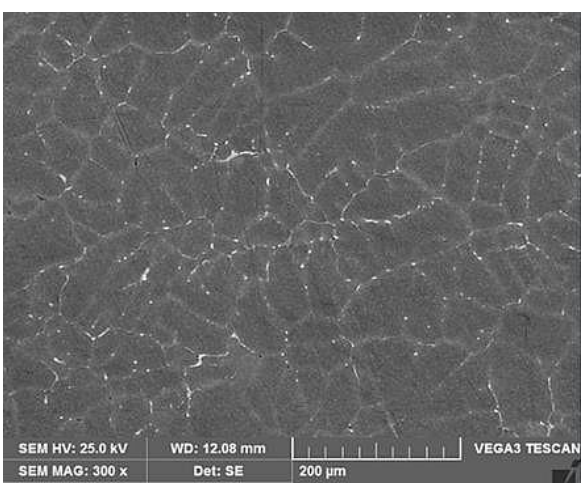

(a)

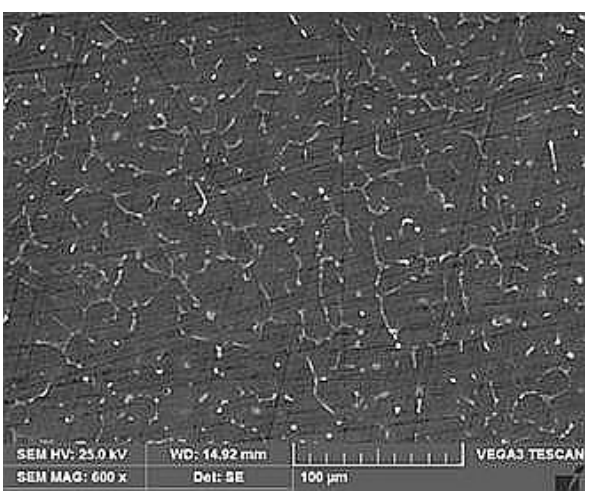

(b) 


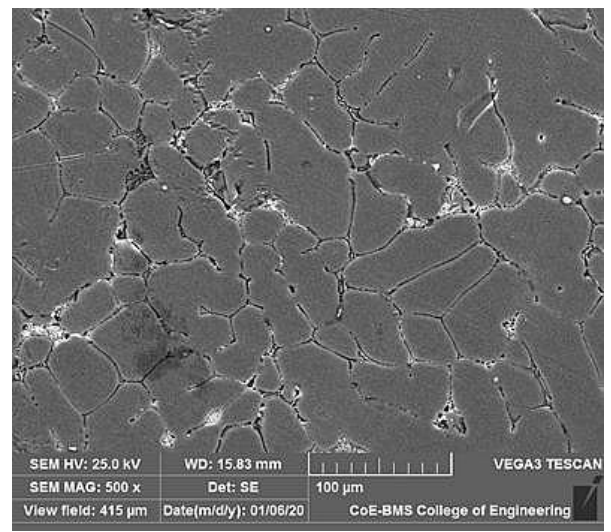

(c)

Figure 18. SEM images of matrix material and its composites. (a) SEM Image of Al6061 grade aluminum alloy; (b) SEM image of Al6061 grade aluminum reinforced with 3\% redmud; (c) SEM image of Al6061 grade aluminum reinforced with 6\% redmud.

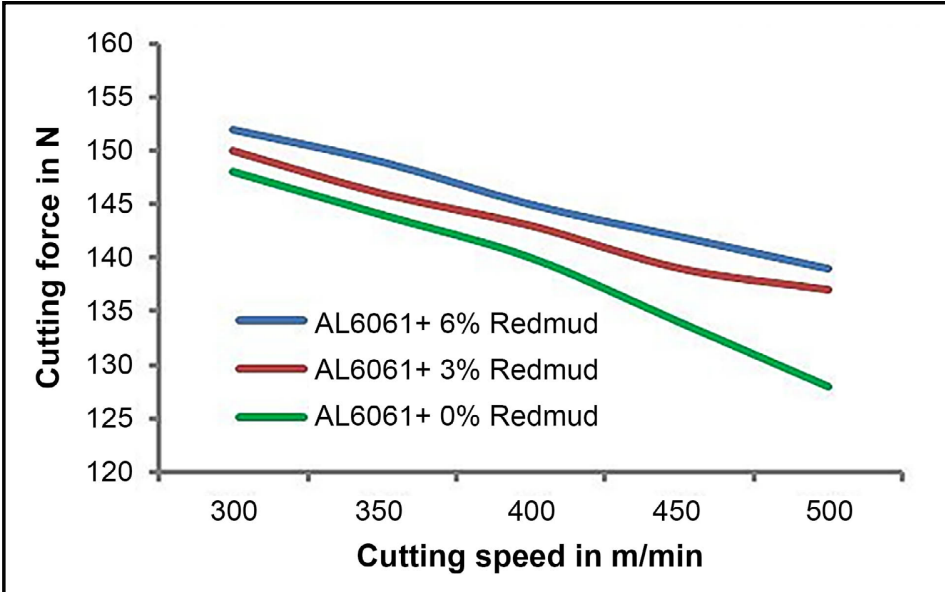

Figure 19. Effect of cutting speed on cutting force while machining Al6061 with varied percent filler at $0.08 \mathrm{~mm} / \mathrm{rev}$. feed.

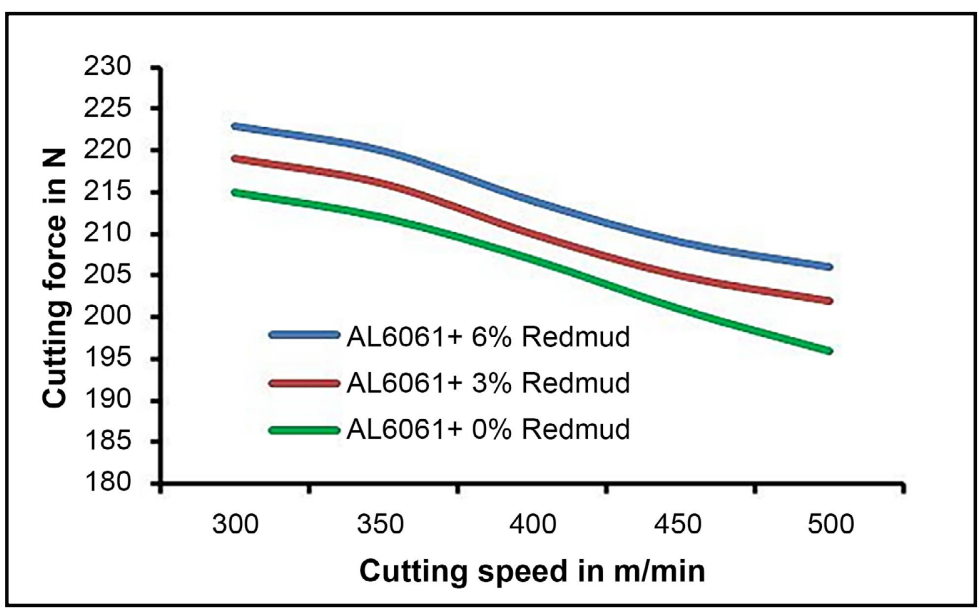

Figure 20. Effect of cutting speed on cutting force while machining Al6061 with varied percent filler at $0.16 \mathrm{~mm} / \mathrm{rev}$. feed. 


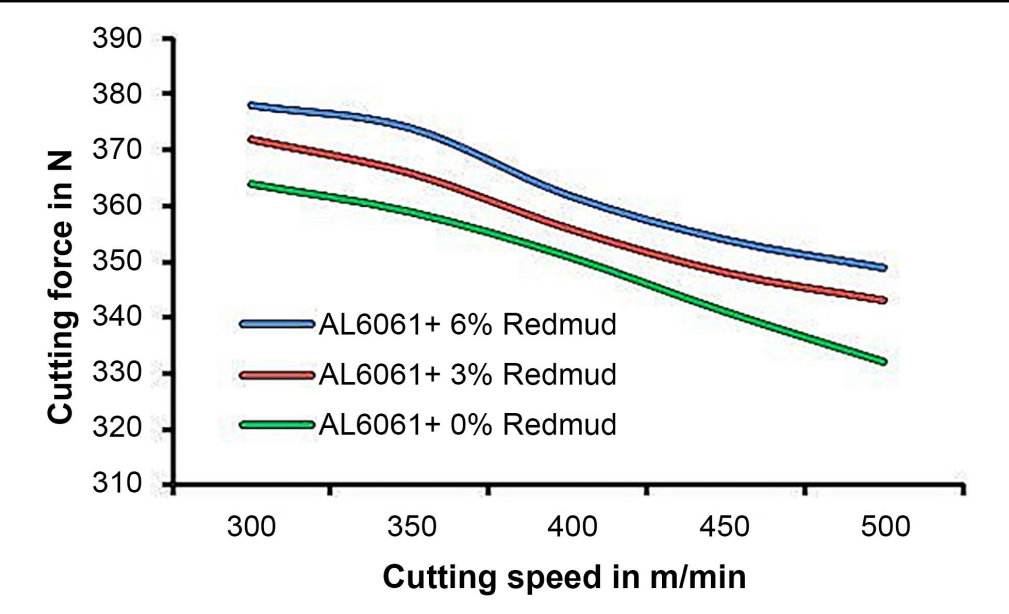

Figure 21. Effect of cutting speed on cutting force while machining Al6061 with varied percent filler at $0.24 \mathrm{~mm} / \mathrm{rev}$. feed.

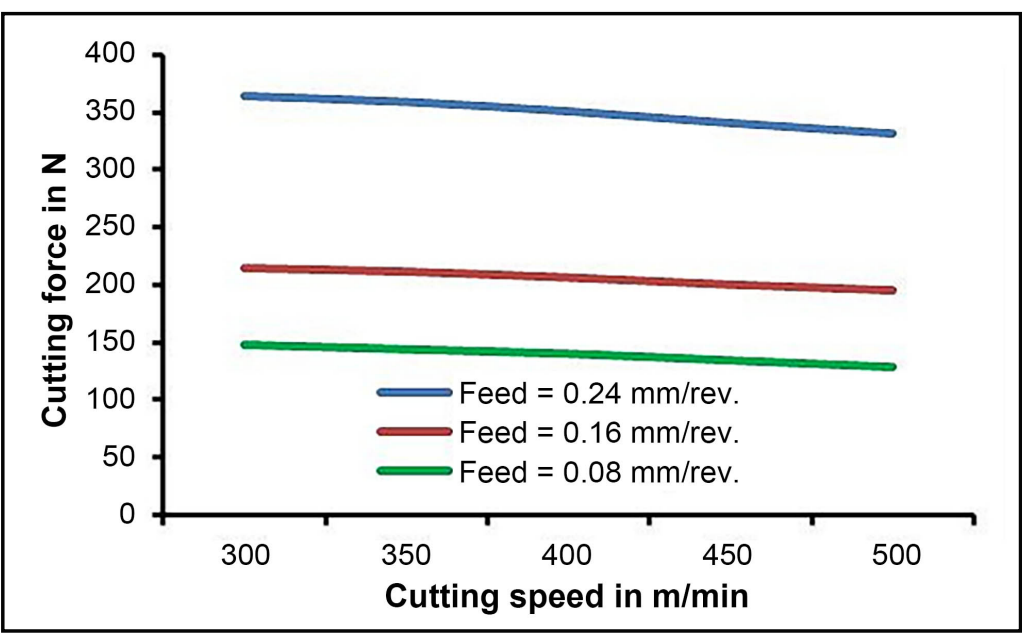

Figure 22. Effect of feed per revolution on cutting force while machining Al6061 with $0 \%$ filler.

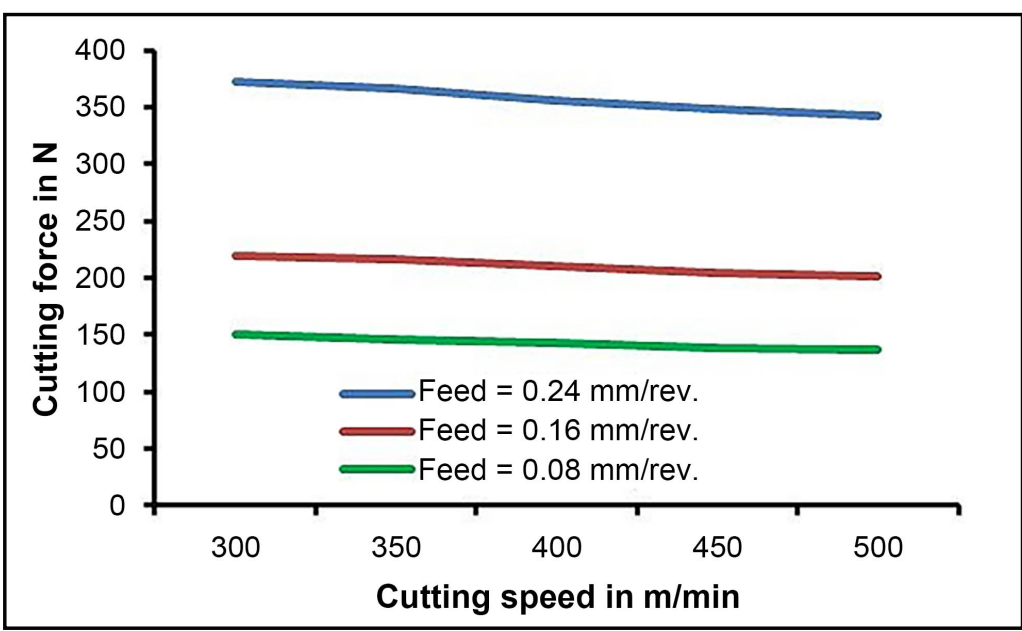

Figure 23. Effect of feed per revolution on cutting force while machining Al6061 with 3\% filler. 


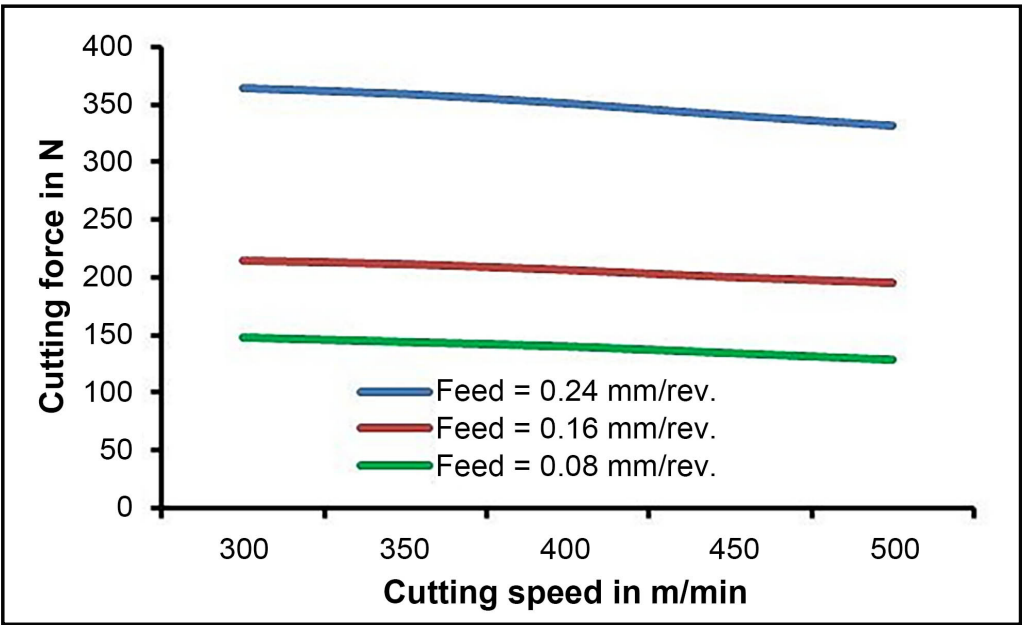

Figure 24. Effect of feed per revolution on cutting force while machining Al6061 with $6 \%$ filler.

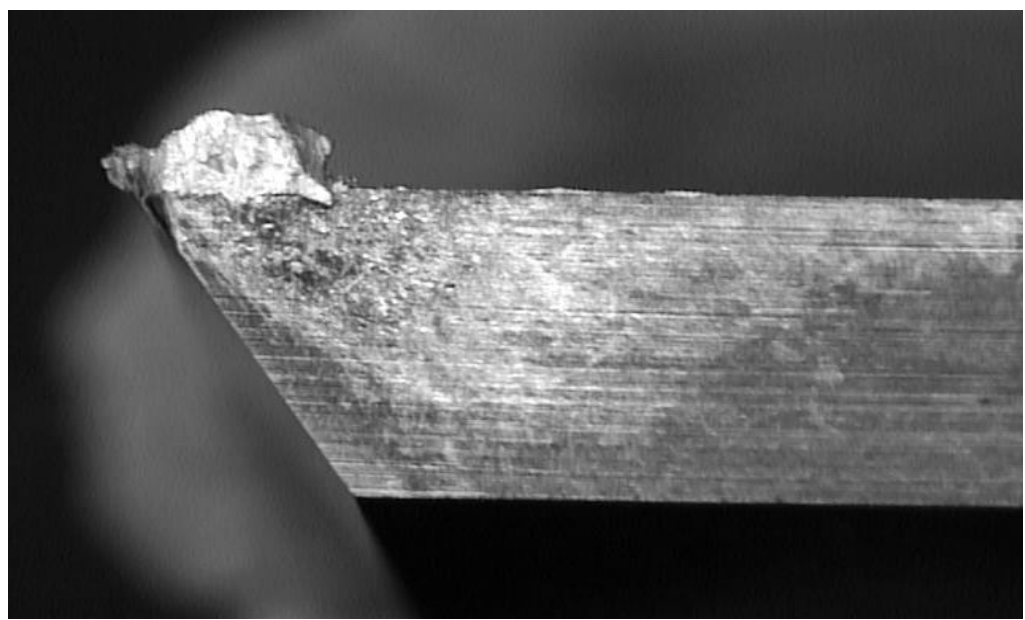

Figure 25. Built up edge observed while machining Aluminum metal matrix composite.

\section{Conclusions}

The conclusions arrived from the research work are:

1) As the percent of red mud increases, the hardness of the composite increases.

2) The density of the composite material decreases with increase of red mud.

3) From SEM images, we can infer that Stir casting method leads to uniform distribution of reinforcement.

4) The cutting force acting on cutting tool decreases with the increase in cutting speed.

5) The cutting force increases when feeding per revolution increases.

6) During machining, with increase in percent of reinforcement in composites to $6 \%$, the cutting force acting on the cutting tool was found higher.

7) Cutting force found least at $0.08 \mathrm{~mm} /$ revolution.

8) Built up edge observed while machining aluminum alloy and its composites, however, the intensity of built up edge formation was found lower while 
machining composite material.

\section{Conflicts of Interest}

The authors declare no conflicts of interest regarding the publication of this paper.

\section{References}

[1] Habibur Rahman, Md. and Mamun Al Rashed, H.M. (2014) Characterization of Silicon Carbide Reinforced Aluminum Matrix Composites. Procedia Engineering, 90, 103-109. https://doi.org/10.1016/j.proeng.2014.11.821

[2] Singla, M., Deepak Dwivedi, D., Singh, L. and Chawla, V. (2009) Development of Aluminium Based Silicon Carbide Particulate Metal Matrix Composite. Journal of Minerals \& Materials Characterization \& Engineering, 8, 455-467. https://doi.org/10.4236/jmmce.2009.86040

[3] Sozhamannan, G.G., Balasivanandha Prabu, S. and Venkatagalapathy, V.S.K. (2012) Effect of Processing Paramters on Metal Matrix Composites: Stir Casting Process. Journal of Surface Engineered Materials and Advanced Technology, 2, 11-15. https://doi.org/10.4236/jsemat.2012.21002

[4] Sirahbizu Yigezu, B., Mohan Mahapatra, M. and Kumar Jha, P. (2013) Influence of Reinforcement Type on Microstructure, Hardness, and Tensile Properties of an Aluminum Alloy Metal Matrix Composite. Journal of Minerals and Materials Characterization and Engineering, 1, 124-130. https://doi.org/10.4236/jmmce.2013.14022

[5] Mujeeb Quader, S., Suryanarayana Murthy, B. and Ravinder Reddy, P. (2016) Processing and Mechanical Properties of $\mathrm{Al}_{2} \mathrm{O}_{3}$ and Red Mud Particle Reinforced AA6061 Hybrid Composites. Journal of Minerals and Materials Characterization and Engineering, 4, 135-142. https://doi.org/10.4236/jmmce.2016.42013

[6] Prakash Rao, C.R., Bhagyashekar, M.S. and Viswanathan, N. (2014) Machining Behaviour of Al6061-Fly Ash Composites. Procedia Materials Science, 5, 1593-1602. https://doi.org/10.1016/j.mspro.2014.07.347

[7] Prakash Rao, C.R., Ravi Kumar, V., Ravi Kumar, D.V., Chandra, P., Vedavyasa, M. and Rajagopal, M.S. (2020) Influence of Machining Parameter on Tool Life While Machining Hybrid Metal Matrix Composites. Journal of Minerals and Materials Characterization and Engineering, 8, 440-458.

https://doi.org/10.4236/jmmce.2020.86028

[8] Behera, R., Das, S., Chatterjee, D. and Sutradhar, G. (2011) Forgeability and Machinability of Stir Cast Aluminum Alloy Metal Matrix Composites. Journal of Minerals \& Materials Characterization \& Engineering, 10, 923-939.

https://doi.org/10.4236/jmmce.2011.1010072

[9] Siddappa, P.N., Shivakumar, B.P., Yogesha, K.B., Mruthunjaya, M. and Hanamantraygouda, M.B (2018) Machinability Study of Al-TiC Metal Matrix Composite. MATEC Web of Conferences, 144, Article No. 03001. https://doi.org/10.1051/matecconf/201814403001

[10] Kumar, A., Mahapatra, M.M. and Jha, P.K. (2014) Effect of Machining Parameters on Cutting Force and Surface Roughness of in Situ $\mathrm{Al}-4.5 \% \mathrm{Cu} / \mathrm{TiC}$ Metal Matrix Composites. Measurement, 48, 325-332. https://doi.org/10.1016/j.measurement.2013.11.026

[11] Quigley, O., Monaghan, J. and Reilly, P.O. (1994) Factors Affecting the Machinability of an Al/SiC Metal-Matrix Composite. Journal of Materials Processing Technol- 
ogy, 43, 21-36. https://doi.org/10.1016/0924-0136(94)90159-7

[12] Fathy, A, Abdelhameed, M. and Shehata F. (2012) Effect of Some Manufacturing Parameters on Machining of Extruded $\mathrm{Al}-\mathrm{Al}_{2} \mathrm{O}_{3}$ Composites. International Scholarly Research Notices, 2012, Article ID: 748734. https://doi.org/10.5402/2012/748734

[13] Hung, N.P., Loh, N.L. and Xu, Z.M. (1996) Cumulative Tool Wear in Machining Metal Matrix Composites, Part II: Machinability. Journal of Materials Processing Technology, 58, 114-120. https://doi.org/10.1016/0924-0136(95)02115-9

[14] Kumar, R., Seenappa, D.V., Prakash Rao, C.R., et al. (2018) Corrosion Behavior of Cenosphere Reinforced Al 7075 Metal Matrix Composite-An Experimental Approach. Journal of Minerals and Materials Characterization and Engineering, 6, 424-437. https://doi.org/10.4236/jmmce.2018.63030

[15] Mohanavel, V., Rajan, K., Senthil, P.V. and Arul, S. (2017) Mechanical Behaviour of Hybrid Composite (AA6351+ $\mathrm{Al}_{2} \mathrm{O}_{3}+\mathrm{Gr}$ ) Fabricated by Stir Casting Method. MaterialsToday: Proceedings, 4, 3093-3101. https://doi.org/10.1016/j.matpr.2017.02.192

[16] Hassanpour, H., Sadeghi, M.H., Rezaei, H. and Rasti, A. (2016) Experimental Study of Cutting Force, Microhardness, Surface Roughness, and Burr Size on Micromilling of Ti6Al4V in Minimum Quantity Lubrication. Materials and Manufacturing Processes, 31, 1654-1662. https://doi.org/10.1080/10426914.2015.1117629

[17] Klocke, F., Nobel, C. and Veselovac, D. (2016) Influence of Tool Coating, Tool Material and Cutting Speed on the Machinability of Low-Leaded Brass Alloys in Turning. Materials and Manufacturing Processes, 31, 1895-1903.

https://doi.org/10.1080/10426914.2015.1127944

[18] Demir, H. and Gunduz, S. (2009) The Effects of Aging on Machinability of 6061 Aluminum Alloy. Materials and Design, 30, 1480-1483.

https://doi.org/10.1016/j.matdes.2008.08.007

[19] Hung, N.P., Yeo, S.H. and Oon, B.E. (1997) Effect of Cutting Fluid on the Machinability of Metal Matrix Composites. Journal of Materials Processing Technology, 67, 157-161. https://doi.org/10.1016/S0924-0136(96)02836-1

[20] Singh, H. and Kumar, P. (2004) Tool Wear Optimization in Turning Operation by Taguchi Method. Indian Journal of Engineering \& Material Sciences, 11, 19-24.

[21] Balasubramanian, K., Nataraj, M. and Duraisamy, P. (2019) Machinability Analysis and Application of Response Surface Approach on CNC Turning of LM6/SiCp Composites. Materials and Manufacturing Processes, 34, 1389-1400. https://doi.org/10.1080/10426914.2019.1660787 